\title{
Mechanisms of transcriptional regulation of ecdysone response
}

\author{
M.Yu. Mazina, N.E. Vorobyeva @ \\ Institute of Gene Biology, RAS, Group of transcriptional complexes dynamics, Moscow, Russia \\ هe-mail: vorobyeva@genebiology.ru
}

\begin{abstract}
The mechanisms of ecdysone-dependent expression have been studied for many decades. Initially, the activation of individual genes under the influence of ecdysone was studied on the model of polythene chromosomes from salivary glands of Drosophila melanogaster. These works helped to investigate the many aspects of the Drosophila development. They also revealed plenty of valuable information regarding the fundamental mechanisms controlling the genes' work. Many years ago, a model describing the process of gene activation by ecdysone, named after the author - Ashburner model - was proposed. This model is still considered an excellent description of the ecdysone cascade, which is implemented in the salivary glands during the formation of the Drosophila pupa. However, these days there is an opinion that the response of cells to the hormone ecdysone can develop with significant differences, depending on the type of cells. The same genes can be activated or repressed under the influence of ecdysone in different tissues. Likely, certain DNA-binding transcription factors that are involved in the ecdysonedependent response together with the EcR/Usp heterodimer are responsible for cell-type specificity. A number of transcriptional regulators involved in the ecdysone response have been described. Among them are several complexes responsible for chromatin remodeling and modification. It has been shown by various methods that ecdysone-dependent activation/repression of gene transcription develops with significant structural changes of chromatin on regulatory elements. The description of the molecular mechanism of this process, in particular, the role of individual proteins in it, as well as structural interactions between various regulatory elements is a matter of the future. This review is aimed to discuss the available information regarding the main regulators that interact with the ecdysone receptor. We provide a brief description of the regulator's participation in the ecdysone response and links to the corresponding study. We also discuss general aspects of the mechanism of ecdysone-dependent regulation and highlight the most promising points for further research.

Key words: transcription; chromatin; regulator; nuclear receptor; EcR; ecdysone; $20 \mathrm{H}$-ecdysone; Drosophila.
\end{abstract}

For citation: Mazina M.Yu., Vorobyeva N.E. Mechanisms of transcriptional regulation of ecdysone response. Vavilovskii Zhurnal Genetiki i Selektsii = Vavilov Journal of Genetics and Breeding. 2019;23(2):212-218. DOI 10.18699/VJ19.484

\section{Механизмы регуляции транскрипции под действием экдизона}

\author{
М.Ю. Мазина, Н.Е. Воробьева 삐 \\ Институт биологии гена Российской академии наук, группа динамики транскрипционных комплексов, Москва, Россия \\ هe-mail: vorobyeva@genebiology.ru
}

\begin{abstract}
Механизмы экспрессии экдизон-зависимых генов исследуются на протяжении нескольких десятилетий. Исходно активация транскрипции отдельных генов под воздействием экдизона была исследована на модели политенных хромосом Drosophila melanogaster. Эти работы помогли изучить многочисленные аспекты развития дрозофилы и выявили ценную информацию относительно фундаментальных механизмов, управляющих работой генов. Модель, описывающая процесс активации генов экдизоном, была предложена еще много лет назад и названа по имени ее автора - Ashburner model. Данная модель до сих пор считается прекрасным описанием экдизонового каскада, который реализуется в слюнных железах во время формирования куколки дрозофилы. Однако к настоящему времени сформировалось понимание того, что ответ клеток на экдизон может развиваться разным образом в зависимости от типа клеток. Под воздействием экдизона одни и те же гены могут активироваться или репрессироваться в клетках различного происхождения. Судя по всему, за такую тканеспецифичность отвечают определенные ДНК-связывающие транскрипционные факторы, которые вовлечены в экдизон-зависимый ответ вместе c EcR/Usp гетеродимером. На сегодняшний день описано множество транскрипционных регуляторов, вовлеченных в процесс экдизонового ответа. Среди них несколько комплексов, ответственных за ремоделирование и модификацию хроматина. Различными методами было показано, что экдизон-зависимая активация/репрессия транскрипции генов протекает со значительными структурными изменениями хроматина на регуляторных элементах. Описание молекулярного механизма этого процесса, в частности роли в нем отдельных белков, а также структурных взаимодействий между различными регуляторными элементами, - дело будущего. Целью нашего обзора является обсуждение имеющейся информации относительно регуляторов транскрипции, взаимодействующих с экдизоновым рецептором. Приведено краткое описание механизма участия регулятора в экдизоновом ответе, а также
\end{abstract}


ссылки на соответствующее исследование. Обсуждаются общие аспекты механизма экдизон-зависимой регуляции транскрипции в свете последних исследований и выделены наиболее перспективные моменты, которые кажутся нам интересными для дальнейшего изучения.

Ключевые слова: транскрипция; хроматин; регулятор; ядерный рецептор; EcR; экдизон; 20H-экдизон; дрозофила.

\section{Introduction}

For the first time, a pure hormone that controls the metamorphosis of insects, was isolated in 1954 (Butenandt, Karlson, 2014). Some time later its biological activity and role in the formation of the Drosophila pupa was confirmed (Chihara et al., 1972). Further, on the experimental model of the polytene chromosomes of Drosophila melanogaster, the role of the ecdysone in the transcriptional activation of developmental genes was discovered (Ashburner, 1971; Ashburner et al., 1974).

The studies of drosophila polytene chromosomes had led to the description of ecdysone cascade (Zhimulev et al., 2004). The concept of the cascade is that ecdysone action on the cells results in the activation of a number of "early" genes important for the process of metamorphosis. Products of these genes in turn are transcriptional regulators that activate subsequent target genes. Many years have been required for researchers to uncover the genes participating in the ecdysone cascade (Thummel, 2002). These studies have led to the fact that currently the main transcription activators of the ecdysone cascade genes (which are mainly nuclear receptors) have been studied quite well. Moreover, the functions of the products of the target genes that they induce have also been investigated. The rather poorly studied part of ecdysone-dependent transcription regulation is the molecular mechanism controlling the activation and repression of target genes, which would include a description of the transcriptional complexes involved in it, as well as the specifics of RNA polymerase II functioning during this process.

\section{Ecdysone-binding complex}

More than two decades ago, the molecular sensor of Drosophila cells - EcR ecdysone receptor - was isolated and cloned (Koelle et al., 1991). It was found that this protein is able to bind to DNA regulatory elements that determine ecdysone sensitivity (EcRE, ecdysone-response elements) and stimulate ecdysone-dependent activation of gene transcription in reporter systems (Antoniewski et al., 1993). The expression profile of the gene encoding ecdysone receptor during the development of Drosophila coincides in time with the expression of the ecdysone cascade genes. The ecdysone receptor belongs to the nuclear receptors, transcription regulator proteins that directly bind to the DNA regulatory elements of their target genes (King-Jones, Thummel, 2005). Quickly enough after the isolation of the gene, encoding EcR in Drosophila, it was found that the expression of this receptor in mammalian cells may result in the ability of these cells to support the expression of ecdysone-dependent reporter systems (Christopherson et al., 1992). The applying of an ecdysone receptor to control the inducible transcription of transgenes in mammalian cells has become quite widespread due to the high specificity of transcription activation mechanisms. The ligand-binding part of the ecdysone receptor served as the basis for the creation of numerous chimeric transcription activators, whose activity depends on the presence of ecdysone and is insensitive to other types of steroid hormones (No et al., 1996).

In Drosophila cells, the functional ecdysone response sensor is a heterodimer formed by an ecdysone receptor with the nuclear receptor Ultraspiracle (Usp). It has been shown that this heterodimer, but not the ecdysone receptor itself, is able to bind ecdysone hormone effectively (Yao et al., 1993). The interaction of the ecdysone receptor with DNA in vivo also occurs better if it is a part of the heterodimer. Mutations in the gene encoding the Usp receptor lead to disruptions in the development of Drosophila, namely the process of formation of the pupa controlled by the ecdysone cascade (Hall, Thummel, 1998). The usp gene mutants demonstrate a damage of the larval cuticle (the formation of a bilayer cuticle due to molting problems), as well as the problems with differentiation of the imaginal discs and with the launch of a cell death program for the salivary glands and the larval intestin.

Using X-ray analysis, the three-dimensional structure of the ligand-binding domains of EcR and Usp receptors was first established in complex with an ecdysone analogue ponasterone $\mathrm{A}$ (ponA), and then with a 20-hydroxyecdysone (Billas et al., 2003; Browning et al., 2007). The ligand-binding pocket for ecdysone hormone is formed entirely by the amino acids of the EcR receptor. Probably, the stimulating role of Usp during the interaction of the heterodimer with ecdysone is to create the necessary stable conformation of the ligandbinding domain of EcR.

EcR and Usp heterodimer is a highly specific sensor of ecdysone and its active metabolite 20-hydroxyecdysone. It is unable to bind other ecdysteroids found in insect hemolymph (Baker et al., 2000). The ability to non-selectively bind ecdysteroids has been found for another nuclear receptor DHR38 (Baker et al., 2003). Interestingly, to form an active complex with various ecdysteroids, the DHR38 receptor interacts with Usp, a partner of the EcR receptor. The discovery of the ability of the DHR38 receptor to bind ecdysteroids explained the presence of morphological differences between mutations of the ecr and usp genes. Mutations of the $d h r 38$ gene, as well as of the $u s p$ gene, show disruption of the cuticle formation, which is not observed in mutations of the ecr gene.

Ecdysone-dependent genes are activated repeatedly during the development of Drosophila. Interestingly, the set of ecdysone-induced genes at different stages of development has some differences. Thus, the e93 gene directly induced by ecdysone is activated in the process of metamorphosis only at the secondary ecdysone peak several hours after the formation of the pupa. It was shown that the activation of the transcription of the $e 93$ gene requires a special "competence" of the cells - the expression of betaftz-f1 early-late gene of the ecdysone cascade. The lack of this transcription factor in the third larval stage explains the insensitivity of the e93 gene to ecdysone in the late third larval stage (Broadus et al., 1999). The exogenous expression of the $f t z-f 1$ in the larvae 
restores the ability of the $e 93$ gene to be induced by ecdysone (Woodard et al., 1994).

Reiterative expression of ecdysone-dependent genes in development suggests the existence of effective mechanisms for suppressing the transcription of previously activated genes. It is believed that the main role in this process is played by the products of the genes of early ecdysone response. Their activity as transcriptional repressors for EcR receptor gene and for some other early response genes forms negative feedback loops in the ecdysone cascade. One of these genes products, the E75A protein, is a transcriptional repressor of the ecr and $b r-c$ genes (Johnston et al., 2011). Interestingly, its activity as a repressor depends on the intracellular concentration of NO. Only heme of the E75A protein, not bound with NO, is able to interact with SMRTER and repress the transcription of target genes. The EcR receptor itself is also able to interact with the SMRTER protein, which is a repressor of ecdysone genes (ecdysone effects the EcR-SMRTER complex in the way that leads to the removal of the repressor from the complex) (Tsai et al., 1999). The smrter gene mutations, as well as the ecr gene mutation, disrupting the interaction of EcR and SMRTER, demonstrate the important role of this repressor in regulating the ecdysone and Notch signaling pathways that control the development of Drosophila (Heck et al., 2012).

Recently, an alternative mechanism for repression of ecdysone-dependent genes transcription has been proposed. It was shown that the dMi-2 factor can replace the Usp in the EcRUsp heterodimer to perform repression of the genes of ecdysone response (Kreher et al., 2017). Moreover, overexpression of dMi-2 is even able to displace Usp from its complex with EcR. Interestingly, during activation of ecdysone-induced genes transcription, an increase in the level of $\mathrm{dMi}-2$ binding to regions of inducible genes is observed (Kreher et al., 2017). Perhaps repressor recruitment protects ecdysone genes from transcription activation being too high and is needed to prepare the gene for ongoing transcriptional repression. Similar properties were found by us earlier for another protein of the CHD group - CHD1. We showed that CHD1 is a transcriptional repressor for $d h r 3$ and $h r 4$ ecdysone genes of early response, but it is recruited to the promoter of these genes in the first minutes after activation of their transcription by ecdysone, together with transcription coactivator complexes (Mazina et al., 2018).

\section{General aspects of ecdysone-dependent transcription regulation}

The molecular mechanisms of ecdysone-dependent activation of transcription are still badly understood because of the complexity of performing the experiments on individual Drosophila tissues at different stages of development. Mechanisms of gene activation are understood as the description of regulators recruitment to the promoters and activation-induced modifications of regulatory proteins and the main enzyme, RNA polymerase II. The presence of a model system of polytene chromosomes in Drosophila allowed researchers to study the transcription mechanisms for individual genes long before the appearance of whole-genome research tools ( Belyaeva et al., 1981; Ashburner, 1990; Gonzy et al., 2002).

It was found that the puffs of ecdysone genes (in particular, $b r, e 74, \mathrm{e} 75)$ in the active state are filled exclusively with phosphorylated form of RNA polymerase II and practically do not contain the enzyme in the non-phosphorylated state (Weeks et al., 1993). This may indicate, firstly, that the elongation of transcription at the active ecdysone genes is carried out by the fully phosphorylated form of RNA polymerase II, and, secondly, that during the active phase of the transcription, the non-phosphorylated enzyme is not recruited, but the phosphorylated form is being re-utilized. The well-known transcription timing of the ecdysone cascade genes in the salivary glands allows it to be used as a model system for studying the participation of proteins in various stages of the transcription process (preparation for it or during active transcription) (Brandt, Corces, 2008).

Unfortunately, it is difficult to investigate the detailed mechanisms of developmental genes transcription activation in tissues. Therefore, much of the research on the mechanisms of ecdysone response was carried out in the experimental system of cultured cells. An important aspect of such studies is the fact that the response of cells to treatment with ecdysone can vary significantly (depending on the presence of additional transcriptional regulators in a particular cell type) (Stoiber et al., 2016). These differences can be so significant that the same gene (for example, CG9932 in the last study) can be activated under the influence of ecdysone in some cells and be repressed in others. This result is quite expected. The fact is that the ecdysone cascade controls the development of Drosophila, namely the transition between different stages. At the same time, the ecdysone cascade can be activated simultaneously in various tissues of the body. Obviously, the development of different organs requires specific patterns of gene activation, that is, the presence of different targets for the ecdysone receptor, depending on the type of tissue.

Several years ago, information began to appear about the possibility of ecdysone-dependent genes regulation by the RNA polymerase II pausing mechanism. It was found that the known factors of RNA polymerase II pausing, NELF and GAF, are associated with ecdysone-dependent promoters of the ecr gene (Lee et al., 2008; Fay et al., 2011). Later our group found that the activation of transcription of ecdysone-dependent $d h r 3$ and $h r 4$ genes in S2 Drosophila cells occurs by stimulating the phosphorylation of RNA polymerase II, associated with the promoters in their inactive state (Mazina et al., 2015). Later, in genome-wide experiments, we showed that such an activation mechanism is inherent to many ecdysone-dependent genes (Mazina et al., 2018).

Of course, whole-genome research methods have brought a lot of valuable information concerning the mechanisms of transcription regulation of ecdysone-dependent genes. Thus, relatively recently, the distinctive features of ecdysonedependent enhancers were characterized by the STARR-Seq whole-genome method in S2 cells (Shlyueva et al., 2014). It turned out that the functioning of these enhancers depends not only on the binding of the heterodimer EcR-Usp, but also on the binding of other transcription factors. It was shown that the mutation of the Serpent binding site leads to a violation of the ecdysone-dependent activity of a number of regulatory elements in S2 cells, and a defect in the binding of traffic jam interferes with the activity of enhancers in the ovarian cells. Shlyueva and colleagues also showed that the vast majority of ecdysone-dependent enhancers are areas of closed chromatin 
Coregulators of ecdysone-dependent transcriptional response

\begin{tabular}{|c|c|c|c|c|}
\hline $\begin{array}{l}\text { Name } \\
\text { of Protein }\end{array}$ & FlyBase ID & References & $\begin{array}{l}\text { Protein } \\
\text { complex }\end{array}$ & Mechanism \\
\hline TRR & FBgn0023518 & $\begin{array}{l}\text { Sedkov et al., 2003; } \\
\text { Carbonell et al., 2013; } \\
\text { Pascual-Garcia et al., } 2017\end{array}$ & TRR complex & $\begin{array}{l}\text { Interacts with EcR, responsible for the incorporation } \\
\text { of H3K4me3 modification onto ecdysone-dependent } \\
\text { promoters }\end{array}$ \\
\hline Tai & FBgn0041092 & $\begin{array}{l}\text { Bai et al., 2000; Xie et al., 2015; } \\
\text { Zhang et al., } 2015\end{array}$ & & $\begin{array}{l}\text { Interacts with EcR and Usp, links EcR signaling to Hippo } \\
\text { pathway }\end{array}$ \\
\hline ISWI & FBgn0011604 & $\begin{array}{l}\text { Badenhorst et al., 2005; Ables, } \\
\text { Drummond-Barbosa, } 2010\end{array}$ & NURF & Directly interacts with EcR in ecdysone-dependent way \\
\hline Cdk8 & FBgn0015618 & $\begin{array}{l}\text { Xie et al., 2015; } \\
\text { Mazina et al., } 2018\end{array}$ & $\begin{array}{l}\text { Mediator } \\
\text { (cdk8 module) }\end{array}$ & $\begin{array}{l}\text { Cdk8 is important for the recruitment of the EcR-Usp } \\
\text { complex }\end{array}$ \\
\hline $\begin{array}{l}\text { Core } \\
\text { mediator } \\
\text { subunits }\end{array}$ & & $\begin{array}{l}\text { Homem et al., 2014; } \\
\text { Xie et al., 2015; } \\
\text { Mazina et al., } 2018\end{array}$ & $\begin{array}{l}\text { Mediator } \\
\text { complex }\end{array}$ & $\begin{array}{l}\text { Interacts with EcR, mediates activation and repression } \\
\text { of ecdysone-dependent genes }\end{array}$ \\
\hline Crc (ATF4) & FBgn0000370 & Gauthier et al., 2012 & & $\begin{array}{l}\text { Binds to B2 isoform of EcR specifically, activates } \\
\text { transcription of ecdysone-dependent eth gene }\end{array}$ \\
\hline lawc & FBgn262976 & Brandt, Corces, 2008 & & Important for productive phase of transcription elongation \\
\hline Ash2 & FBgn0000139 & Carbonell et al., 2013 & TRR complex & $\begin{array}{l}\text { Interacts with TRR, stabilizes it and facilitates H3K4me3 } \\
\text { incorporation at promoters }\end{array}$ \\
\hline dDEK & FBgn 0026533 & Sawatsubashi et al., 2010 & $\begin{array}{l}\text { dDEK-dCK2 } \\
\text { complex }\end{array}$ & $\begin{array}{l}\text { Interacts with EcR, works as histone chaperone, stimulates } \\
\text { incorporation of H3.3 at ecdysone dependent genes }\end{array}$ \\
\hline Nup98 & FBgn0039120 & Pascual-Garcia et al., 2017 & Nuclear pore & $\begin{array}{l}\text { Contributes to transcriptional memory and enhancer } \\
\text { looping of ecdysone-dependent genes }\end{array}$ \\
\hline Mtor & FBgn0013756 & Pascual-Garcia et al., 2017 & $\begin{array}{l}\text { Nuclear pore } \\
\text { basket }\end{array}$ & $\begin{array}{l}\text { Contributes to transcriptional memory of ecdysone- } \\
\text { dependent genes }\end{array}$ \\
\hline Putzig & FBgn0259785 & Kugler et al., 2011 & $\begin{array}{l}\text { Associated } \\
\text { with NURF }\end{array}$ & Interacts with EcR in vivo, promotes ecdysone signaling \\
\hline SAYP & FBgn0087008 & Vorobyeva et al., 2011, 2012 & $\mathrm{SWI} / \mathrm{SNF}$ & Involved in ecdysone-dependent Pol II pausing \\
\hline Snr1 & FBgn0011715 & $\begin{array}{l}\text { Zraly et al., 2006; } \\
\text { Zraly, Dingwall, } 2012\end{array}$ & SWI/SNF & $\begin{array}{l}\text { Repression of ecdysone-dependent genes, involved in Pol II } \\
\text { elongation and splicing processes }\end{array}$ \\
\hline Brm & FBgn0000212 & $\begin{array}{l}\text { Zraly et al., 2006; } \\
\text { Mazina et al., } 2018\end{array}$ & SWI/SNF & Activation and repression of ecdysone-dependent genes \\
\hline $\begin{array}{l}\text { Neiire } \\
\text { (CBP/p300) }\end{array}$ & FBgn0261617 & $\begin{array}{l}\text { Kirilly et al., 2011; } \\
\text { Bodai et al., 2012; } \\
\text { Mazina et al., } 2018\end{array}$ & & $\begin{array}{l}\text { Interacts with EcR in ecdysone-dependent way, promotes } \\
\text { Histone H3 K27 acetylation at ecdysone-dependent } \\
\text { genes, is important for ecdysone-dependent transcription } \\
\text { activation }\end{array}$ \\
\hline DART1 & FBgn0037834 & Mazina et al., 2018 & & $\begin{array}{l}\text { Involved in ecdysone-dependent transcription activation } \\
\text { (may be not connected to its H3R2 methylation activity) }\end{array}$ \\
\hline $\begin{array}{l}\text { Antimeros } \\
\text { (Paf1) }\end{array}$ & FBgn0010750 & Mazina et al., 2018 & PAF complex & $\begin{array}{l}\text { Important for ecdysone dependent transcription activation } \\
\text { (stimulates Pol II CTD Ser2 phosphorylation) }\end{array}$ \\
\hline Mi2 & FBgn0262519 & Kreher et al., 2017 & NURD & $\begin{array}{l}\text { Interacts with EcR (complex devoid of Usp), constrains } \\
\text { transcription of ecdysone-dependent genes }\end{array}$ \\
\hline SMRTER & FBgn0265523 & $\begin{array}{l}\text { Tsai et al., 1999; Johnston } \\
\text { et al., 2011; Heck et al., } 2012\end{array}$ & & Repressor of ecdysone-dependent transcription \\
\hline DOR & FBgn0035542 & Francis et al., 2010 & & ulator of ecdys \\
\hline
\end{tabular}

in an inactive state. Thus, the process of ecdysone-dependent activation of transcription probably involves the remodeling of chromatin on regulatory elements. This observation was confirmed recently by other researchers. It turned out that the remodeling and opening of chromatin on enhancer regulatory elements are the most important steps in controlling the start of transcription of at least for some ecdysone-dependent genes (Uyehara et al., 2017). Disruption of chromatin remodeling on enhancers can interfere with the process of gene activation, or lead to their untimely transcription. Interestingly, many genes involved in the ecdysone cascade are the very proteins that control chromatin density on enhancers at different stages of 
development. It was shown that the $e 93$ gene, a well-known participant of the ecdysone cascade, can take part in both the opening and closing of chromatin on enhancers of genes expressed in wing tissue. Unfortunately, at the moment it is not clear at what stage $e 93$ interferes with the remodeling process: is it the initiator of the process, or does it play a role in its progression.

Various groups of researchers have demonstrated that the efficiency of ecdysone activation depends on the number of ecdysone response regulatory elements in the activated gene (Bernardo et al., 2014; Shlyueva et al., 2014). The 3C (chromatin conformation capture) analysis reveals the presence of interactions between ecdysone-dependent regulatory elements and inducible gene promoters. Probably, the ecdysone-dependent activation of transcription proceeds as a complex multi-component process involving transcription proteins associated with various regulatory elements. Experiments on individual genes demonstrate the involvement of the EcR receptor in the process of remote interactions between DNA elements (Bernardo et al., 2014). However, additional investigations are required to establish whether this statement extends to other ecdysone-dependent genes and what are the additional participants of this particular process.

\section{Coregulators of ecdysone-dependent transcriptional response}

At present, quite a lot of transcription regulator proteins participating in ecdysone-dependent transcription has been shown. Thorough screenings were even performed to find the complete set of such regulators (Davis et al., 2011). Unfortunately, there is relatively little information about the mechanisms of participation of these regulators in the ecdysone response. In a table, we collected information on the most studied ecdysone response regulators.

\section{Perspectives}

Despite the fact that the process of ecdysone-dependent transcriptional regulation has been under thorough examination for many decades, many aspects of it still remain unclear. One of them is the type of transcriptional regulation of ecdysonedependent genes. Currently, it is known that transcription activation can be carried out by stimulating many stages of this process: recruitment of RNA polymerase II, initiating the synthesis of mRNA and stimulating polymerase withdrawal from the promoter, the phase of Pol II transition into the stage of productive elongation. It would be extremely interesting to establish which stages of regulation and in what proportion are utilized by ecdysone-dependent genes. An equally interesting question is whether the way of regulating the same genes changes at different stages of development or in different tissues.

Currently, quite a few ecdysone-dependent transcription regulators are described. Unfortunately, for the most of them the molecular mechanism describing their involvement in the process is either not investigated at all or not studied in sufficient detail. The most important aspect of the study of these regulators will be a comparison of their functions on different ecdysone-dependent genes. Already available information demonstrates that the molecular mechanism of activation may be different even for genes that are activated at the same stages of the ecdysone cascade. Probably, it is this plasticity of the ecdysone response regulation that allows it to become the leading element controlling the development of Drosophila.

\section{References}

Ables E.T., Drummond-Barbosa D. The steroid hormone ecdysone functions with intrinsic chromatin remodeling factors to control female germline stem cells in Drosophila. Cell Stem Cell. 2010;7:581592. DOI 10.1016/j.stem.2010.10.001.

Antoniewski C., Laval M., Lepesant J.-A. Structural features critical to the activity of an ecdysone receptor binding site. Insect Biochem. Mol. Biol. 1993;23:105-114.

Ashburner M. Induction of puffs in polytene chromosomes of in vitro cultured salivary glands of Drosophila melanogaster by ecdysone and ecdysone analogues. Nature. New Biol. 1971;230:222-224.

Ashburner M. Puffs, genes, and hormones revisited. Cell. 1990;61:1-3.

Ashburner M., Chihara C., Meltzer P., Richards G. Temporal control of puffing activity in polytene chromosomes. Cold Spring Harb. Symp. Quant. Biol. 1974;38:655-662.

Badenhorst P., Xiao H., Cherbas L., Kwon S.Y., Voas M., Rebay I., Cherbas P., Wu C. The Drosophila nucleosome remodeling factor NURF is required for Ecdysteroid signaling and metamorphosis. Genes Dev. 2005;19:2540-2545. DOI 10.1101/gad.1342605.

Bai J., Uehara Y., Montell D.J. Regulation of invasive cell behavior by Taiman, a Drosophila protein related to AIB1, a steroid receptor coactivator amplified in breast cancer. Cell. 2000;103:1047-1058.

Baker K.D., Shewchuk L.M., Kozlova T., Makishima M., Hassell A., Wisely B., Caravella J.A., Lambert M.H., Reinking J.L., Krause H., Thummel C.S., Willson T.M., Mangelsdorf D.J. The Drosophila orphan nuclear receptor DHR38 mediates an atypical ecdysteroid signaling pathway. Cell. 2003;113:731-742. DOI 10.1016/S00928674(03)00420-3.

Baker K.D., Warren J.T., Thummel C.S., Gilbert L.I., Mangelsdorf D.J. Transcriptional activation of the Drosophila ecdysone receptor by insect and plant ecdysteroids. Insect Biochem. Mol. Biol. 2000;30: 1037-1043. DOI 10.1016/S0965-1748(00)00075-8.

Belyaeva E.S., Vlassova I.E., Biyasheva Z.M., Kakpakov V.T., Richards G., Zhimulev I.F. Cytogenetic analysis of the 2B3-4-2B11 region of the $\mathrm{X}$ chromosome of Drosophila melanogaster. II. Changes in 20-OH ecdysone puffing caused by genetic defects of puff $2 \mathrm{~B} 5$. Chromosoma. 1981;84:207-219.

Bernardo T.J., Dubrovskaya V.A., Xie X., Dubrovsky E.B. A view through a chromatin loop: insights into the ecdysone activation of early genes in Drosophila. Nucleic Acids Res. 2014;42:1040910424. DOI 10.1093/nar/gku754.

Billas I.M.L., Iwema T., Garnier J.-M., Mitschler A., Rochel N., Moras D. Structural adaptability in the ligand-binding pocket of the ecdysone hormone receptor. Nature. 2003;426:91-96.

Bodai L., Zsindely N., Gáspár R., Kristó I., Komonyi O., Boros I.M. Ecdysone induced gene expression is associated with acetylation of histone H3 lysine 23 in Drosophila melanogaster. PLoS One. 2012;7:e40565. DOI 10.1371/journal.pone.0040565.

Brandt T., Corces V.G. The Lawc protein is required for proper transcription by RNA polymerase II in Drosophila. Mol. Genet. Genomics. 2008;280:385-396. DOI 10.1007/s00438-008-0372-z.

Broadus J., McCabe J.R., Endrizzi B., Thummel C.S., Woodard C.T. The Drosophila $\beta$ FTZ-F1 orphan nuclear receptor provides competence for stage-specific responses to the steroid hormone ecdysone. Mol. Cell. 1999;3:143-149. DOI 10.1016/S1097-2765(00)80305-6.

Browning C., Martin E., Loch C., Wurtz J.-M., Moras D., Stote R.H., Dejaegere A.P., Billas I.M.L. Critical role of desolvation in the binding of 20-hydroxyecdysone to the ecdysone receptor. J. Biol. Chem. 2007;282:32924-32934. DOI 10.1074/jbc.M705559200.

Butenandt A., Karlson P. Über die Isolierung eines Metamorphose-Hormons der Insekten in kristallisierter Form. Z. für Naturforschung B. 2014;9(6):389-391. DOI 10.1515/znb-1954-0601 
Carbonell A., Mazo A., Serras F., Corominas M. Ash2 acts as an ecdysone receptor coactivator by stabilizing the histone methyltransferase Trr. Mol. Biol. Cell. 2013;24:361-372.

Chihara C.J., Petri W.H., Fristrom J.W., King D.S. The assay of ecdysones and juvenile hormones on Drosophila imaginal disks in vitro. J. Insect Physiol. 1972;18:1115-1123.

Christopherson K.S., Mark M.R., Bajaj V., Godowski P.J. Ecdysteroiddependent regulation of genes in mammalian cells by a Drosophila ecdysone receptor and chimeric transactivators. Proc. Natl. Acad. Sci. USA. 1992;89:6314-6318.

Davis M.B., SanGil I., Berry G., Olayokun R., Neves L.H. Identification of common and cell type specific LXXLL motif EcR cofactors using a bioinformatics refined candidate RNAi screen in Drosophila melanogaster cell lines. BMC Dev. Biol. 2011;11:66. DOI 10.1186/1471-213X-11-66.

Fay A., Misulovin Z., Li J., Schaaf C.A., Gause M., Gilmour D.S., Dorsett D. Cohesin selectively binds and regulates genes with paused RNA polymerase. Curr. Biol. 2011;21:1624-1634. DOI 10.1016/j.cub.2011.08.036.

Francis V.A., Zorzano A., Teleman A.A. dDOR is an EcR coactivator that forms a feed-forward loop connecting insulin and ecdysone signaling. Curr. Biol. 2010;20:1799-1808. DOI 10.1016/j.cub. 2010.08.055.

Gauthier S.A., VanHaaften E., Cherbas L., Cherbas P., Hewes R.S. Cryptocephal, the Drosophila melanogaster ATF4, is a specific coactivator for ecdysone receptor isoform B2. PLoS Genet. 2012;8: e1002883. DOI 10.1371/journal.pgen.1002883.

Gonzy G., Pokholkova G.V., Peronnet F., Mugat B., Demakova O.V., Kotlikova I.V., Lepesant J.-A., Zhimulev I.F. Isolation and characterization of novel mutations of the Broad-Complex, a key regulatory gene of ecdysone induction in Drosophila melanogaster. Insect Biochem. Mol. Biol. 2002;32:121-132.

Hall B.L., Thummel C.S. The RXR homolog ultraspiracle is an essential component of the Drosophila ecdysone receptor. Development. 1998;125;4709-4717.

Heck B.W., Zhang B., Tong X., Pan Z., Deng W.-M., Tsai C.-C. The transcriptional corepressor SMRTER influences both Notch and ecdysone signaling during Drosophila development. Biol. Open. 2012; 1:182-196. DOI 10.1242/bio.2012047.

Homem C.C.F., Steinmann V., Burkard T.R., Jais A., Esterbauer H., Knoblich J.A. Ecdysone and Mediator change energy metabolism to terminate proliferation in Drosophila neural stem cells. Cell. 2014; 158:874-888. DOI 10.1016/j.cell.2014.06.024.

Johnston D.M., Sedkov Y., Petruk S., Riley K.M., Fujioka M., Jaynes J.B., Mazo A. Ecdysone- and NO-mediated gene regulation by competing EcR/Usp and E75A nuclear receptors during Drosophila development. Mol. Cell. 2011;44:51-61. DOI 10.1016/ j.molcel. 2011.07.033.

King-Jones K., Thummel C.S. Nuclear receptors - a perspective from Drosophila. Nat. Rev. Genet. 2005;6:311-323.

Kirilly D., Wong J.J., Lim E.K., Wang Y., Zhang H., Wang C., Liao Q., Wang H., Liou Y.-C., Wang H., Yu F. Intrinsic epigenetic factors cooperate with the steroid hormone ecdysone to govern dendrite pruning in Drosophila. Neuron. 2011;72:86-100. DOI 10.1016/j.neuron. 2011.08.003.

Koelle M.R., Talbot W.S., Segraves W.A., Bender M.T., Cherbas P., Hogness D.S. The drosophila $E c R$ gene encodes an ecdysone receptor, a new member of the steroid receptor superfamily. Cell. 1991;67:59-77. DOI 10.1016/0092-8674(91)90572-G.

Kreher J., Kovač K., Bouazoune K., Mačinković I., Ernst A.L., Engelen E., Pahl R., Finkernagel F., Murawska M., Ullah I., Brehm A. EcR recruits dMi-2 and increases efficiency of dMi-2-mediated remodelling to constrain transcription of hormone-regulated genes. Nat. Commun. 2017;8:14806. DOI 10.1038/ncomms 14806.

Kugler S.J., Gehring E.-M., Wallkamm V., Krüger V., Nagel A.C. The Putzig-NURF nucleosome remodeling complex is required for ec- dysone receptor signaling and innate immunity in Drosophila melanogaster. Genetics. 2011;188:127-139. DOI 10.1534/genetics.111. 127795.

Lee C., Li X., Hechmer A., Eisen M., Biggin M.D., Venters B.J., Jiang C., Li J., Pugh B.F., Gilmour D.S. NELF and GAGA factor are linked to promoter-proximal pausing at many genes in Drosophila. Mol. Cell. Biol. 2008;28:3290-3300. DOI 10.1128/MCB. 02224-07.

Mazina M.Y., Kovalenko E.V., Derevyanko P.K., Nikolenko J.V., Krasnov A.N., Vorobyeva N.E. One signal stimulates different transcriptional activation mechanisms. Biochim. Biophys. Acta (BBA) Gene Regul. Mech. 2018;1861:178-189. DOI 10.1016/j.bbagrm. 2018.01.016.

Mazina M.Y., Nikolenko J.V., Fursova N.A., Nedil'ko P.N., Krasnov A.N., Vorobyeva N.E. Early-late genes of the ecdysone cascade as models for transcriptional studies. Cell Cycle Georget. Tex. 2015; 14:3593-3601. DOI 10.1080/15384101.2015.1100772.

No D., Yao T.P., Evans R.M. Ecdysone-inducible gene expression in mammalian cells and transgenic mice. Proc. Natl. Acad. Sci. USA. 1996;93:3346-3351.

Pascual-Garcia P., Debo B., Aleman J.R., Talamas J.A., Lan Y., Nguyen N.H., Won K.J., Capelson M. Metazoan nuclear pores provide a scaffold for poised genes and mediate induced enhancer-promoter contacts. Mol. Cell. 2017;66:63-76. DOI 10.1016/j.molcel. 2017.02.020.

Sawatsubashi S., Murata T., Lim J., Fujiki R., Ito S., Suzuki E., Tanabe M., Zhao Y., Kimura S., Fujiyama S., Ueda T., Umetsu D., Ito T., Takeyama K.-i., Kato S. A histone chaperone, DEK, transcriptionally coactivates a nuclear receptor. Genes Dev. 2010;24:159170. DOI $0.1101 /$ gad. 1857410 .

Sedkov Y., Cho E., Petruk S., Cherbas L., Smith S.T., Jones R.S., Cherbas P., Canaani E., Jaynes J.B., Mazo A. Methylation at lysine 4 of histone $\mathrm{H} 3$ in ecdysone-dependent development of Drosophila. Nature. 2003;426:78-83.

Shlyueva D., Stelzer C., Gerlach D., Yáñez-Cuna J.O., Rath M., Boryń Ł.M., Arnold C.D., Stark A. Hormone-responsive enhancer-activity maps reveal predictive motifs, indirect repression, and targeting of closed chromatin. Mol. Cell. 2014;54:180-192. DOI 10.1016/j.molcel.2014.02.026.

Stoiber M., Celniker S., Cherbas L., Brown B., Cherbas P. Diverse hormone response networks in 41 independent Drosophila cell lines. G3: Genes Genomes Genetics. 2016;6:683-694. DOI 10.1534/g3. 115.023366 .

Thummel C.S. Ecdysone-regulated puff genes 2000. Insect Biochem. Mol. Biol. 2002;32:113-120. DOI 10.1016/S0965-1748(01)00112-6.

Tsai C.C., Kao H.Y., Yao T.P., McKeown M., Evans R.M. SMRTER, a Drosophila nuclear receptor coregulator, reveals that EcR-mediated repression is critical for development. Mol. Cell. 1999;4:175-186. DOI 10.1016/S1097-2765(00)80365-2.

Uyehara C.M., Nystrom S.L., Niederhuber M.J., Leatham-Jensen M., Ma Y., Buttitta L.A., McKay D.J. Hormone-dependent control of developmental timing through regulation of chromatin accessibility. Genes Dev. 2017;31:862-875. DOI 10.1101/gad.298182.117.

Vorobyeva N.E., Nikolenko J.V., Krasnov A.N., Kuzmina J.L., Panov V.V., Nabirochkina E.N., Georgieva S.G., Shidlovskii Y.V. SAYP interacts with DHR3 nuclear receptor and participates in ecdysone-dependent transcription regulation. Cell. Cycle. 2011;10:18211827. DOI 10.4161/cc.10.11.15727.

Vorobyeva N.E., Nikolenko J.V., Nabirochkina E.N., Krasnov A.N., Shidlovskii Y.V., Georgieva S.G. SAYP and Brahma are important for 'repressive' and 'transient' Pol II pausing. Nucleic Acids Res. 2012;40:7319-7331. DOI 10.1093/nar/gks472.

Weeks J.R., Hardin S.E., Shen J., Lee J.M., Greenleaf A.L. Locusspecific variation in phosphorylation state of RNA polymerase II in vivo: correlations with gene activity and transcript processing. Genes Dev. 1993;7:2329-2344. 
Woodard C.T., Baehrecke E.H., Thummel C.S. A molecular mechanism for the stage specificity of the Drosophila prepupal genetic response to ecdysone. Cell. 1994;79:607-615.

Xie X.-J., Hsu F.-N., Gao X., Xu W., Ni J.-Q., Xing Y., Huang L., Hsiao H.-C., Zheng H., Wang C., Zheng Y., Xiaoli A.M., Yang F., Bondos S.E., Ji J.Y. CDK8-Cyclin C mediates nutritional regulation of developmental transitions through the ecdysone receptor in Drosophila. PLoS Biol. 2015;13:e1002207. DOI 10.1371/journal. pbio.1002207.

Yao T.-P., Forman B.M., Jiang Z., Cherbas L., Chen J.-D., McKeown M., Cherbas P., Evans R.M. Functional ecdysone receptor is the product of $E c R$ and Ultraspiracle genes. Nature. 1993;366:476479.

Zhang C., Robinson B.S., Xu W., Yang L., Yao B., Zhao H., Byun P.K., Jin P., Veraksa A., Moberg K.H. The ecdysone receptor coactiva- tor Taiman links Yorkie to transcriptional control of germline stem cell factors in somatic tissue. Dev. Cell. 2015;34:168-180. DOI 10.1016/j.devcel.2015.05.010.

Zhimulev I.F., Belyaeva E.S., Semeshin V.F., Koryakov D.E., Demakov S.A., Demakova O.V., Pokholkova G.V., Andreyeva E.N. Polytene chromosomes: 70 years of genetic research. Int. Rev. Cytol. 2004;241:203-275.

Zraly C.B., Dingwall A.K. The chromatin remodeling and mRNA splicing functions of the Brahma (SWI/SNF) complex are mediated by the SNR1/SNF5 regulatory subunit. Nucleic Acids Res. 2012; 40:5975-5987. DOI 10.1093/nar/gks288.

Zraly C.B., Middleton F.A., Dingwall A.K. Hormone-response genes are direct in vivo regulatory targets of Brahma (SWI/SNF) complex function. J. Biol. Chem. 2006;281:35305-35315. DOI 10.1074/jbc. M607806200.

\section{ORCID ID}

M.Yu. Mazina orcid.org/0000-0002-0480-0553

N.E. Vorobyeva orcid.org/0000-0003-4293-834X

Acknowledgements. This work was supported by Russian Science Foundation, project number 18-14-00219.

Conflict of interest. The authors declare no conflict of interest.

Received November 22, 2018. Revised December 11, 2018. Accepted December 11, 2018. 